\title{
Call It Consumption! Re-Conceptualizing Ecotourism as Consumption and Consumptive
}

\author{
Zoë A. Meletis* and Lisa M. Campbell
}

Nicholas School of the Environment and Earth Sciences, Duke University

\begin{abstract}
Labeling ecotourism as 'non-consumptive' and contrasting it with direct uses of wildlife through activities such as hunting is common practice among organizations and academics primarily concerned with conservation. We interrogate this binary opposition by questioning the assumptions underlying it, namely that 'the direct consumption of wildlife' (i) does not occur in ecotourism; (ii) is incompatible with ecotourism; (iii) is the primary concern; and (iv) is inferior to ecotourism as both a conservation and development strategy. Based on a review of the relevant theoretical and case-study based literature, as well as our own research, we argue that categorizing ecotourism as 'non-consumptive' is not only inaccurate, but also has consequences for both environments and people. We suggest ways in which ecotourism can be re-conceptualized in order to better achieve its goals of conserving both nature and culture, and of contributing to both conservation and development.
\end{abstract}

\section{Introduction}

Despite existing critiques (e.g. Charnley 2005; Duffy 2002; Honey 1999; Kiss 2004; Lindberg et al. 1996), ecotourism has emerged as a widely promoted strategy for reconciling wildlife conservation with human development. This is particularly the case among conservation organizations, for example World Wildlife Fund (News 2004; Troëng and Drews 2004) and Conservation International (Conservation International 2004), and among academics and practitioners primarily concerned with wildlife (and more generally with nature) conservation (Tisdell and Wilson 2002). The promotion of ecotourism has been particularly noticeable in developing countries (Campbell 1999; Mowforth and Munt 1998; Weaver 1998). While there are many definitions of ecotourism in the literature, for the purposes of this article we include two of those most commonly cited. 'Ecological tourism', or 'ecotourism' as defined by the World Conservation Union (IUCN)'s Ecotourism Programme is 'environmentally responsible travel and visitation to relatively undisturbed natural areas, in order to enjoy and appreciate nature (and any accompanying cultural features - both past and present) that promotes conservation, has low visitor impact, and provides for beneficially active 
socio-economic involvement of local populations' (Ceballos-Lascuráin 1993a; cited in Ceballos-Lascuráin 1996, 20). The International Ecotourism Society (no date given) defines ecotourism as 'responsible travel to natural areas that conserves the environment and improves the well-being of local people'. Combined, these definitions highlight two common features of ecotourism definitions: first, that ecotourism can feature both natural and cultural attractions and second, that it has both environmental conservation and socio-economic development goals.

In conservation literature, ecotourism is often categorized as nonconsumptive use of wildlife (and other environmental features) and contrasted with consumptive use. For example, writing about sea turtle tourism and whale watching, Wilson and Tisdell (2003) write:

...[T]hese two resources have been increasingly used for nonconsumptive purposes, marking a significant shift away from previous consumptive uses. Many countries, previously using these resources for consumption, are now turning to nonconsumptive uses in the form of nature-based tourism. (p. 50)

Consumptive use is typically defined as the direct use or removal of wildlife through activities such as hunting (Freese 1998). In contrast, 'While ecotourism can impact negatively on species and ecosystems, a definition of consumptive use based strictly on "deliberate removal of a species" excludes ecotourism' (Campbell 2002b, 31). Labeling ecotourism as non-consumptive is based on several assumptions, however, namely that no direct consumption of wildlife occurs in ecotourism, that the direct consumption of wildlife is incompatible with ecotourism, and that the direct consumption of wildlife is the primary issue of concern. Furthermore, non-consumptive use is often assumed to be a superior economic and environmental alternative to the consumptive use of wildlife. These assumptions have been challenged by geographers and other social scientists, and we draw on their work and our own research to demonstrate how labeling ecotourism as non-consumptive is not only misleading, but carries potential consequences for both local peoples and environments in ecotourism destinations. We also situate ecotourism in wider contemporary debates about the nature of consumption, and specifically regarding alternative consumption and moralizing consumption.

Prior to doing so, several caveats are noted here. First, a vast literature on ecotourism has emerged over the past two decades, much of it increasingly critical (e.g. Cater 2006; Duffy 2002; Honey 1999; Mowforth and Munt 1998; Weaver 1999; Wheeler 1994). While the problems with ecotourism are widely recognized in the tourism literature, enthusiasm for ecotourism remains in some of the major conservation organizations. It is in this context that we find assumptions about the non-consumptive nature of ecotourism particularly problematic. Second, debates about the meaning of ecotourism and the utility of term are also evident, and some critics outline criteria that need to be met for ecotourism to succeed (Ross and 
Wall 1999; Scheyvens 1999, 70). In this article, we accept claims to ecotourism at face value; if destinations, promoters, national governments, and tourists believe that what they are engaging in is ecotourism, academic acceptance or rejection of such claims is to a certain extent irrelevant. For example, in one of the cases discussed in this article, over 80,000 'ecotourists' visit Tortuguero National Park, Costa Rica. Despite these large numbers of visitors and problems with environmental planning and management, Tortuguero is considered an ecotourism destination by actors of all kinds, at all scales, including environmental non-governmental organizations, the Costa Rican government, tour operators, local businesses, and tourists (Caribbean Conservation Corporation 2003; Cuevas and The Caribbean Conservation Corporation 2002; Harrison et al. 2004; Smith 2005; Troëng 2004; Troëng and Drews 2004). Finally, while we are critical of ecotourism, we also accept that it is with us for the foreseeable future. As a result, we finish our article with suggestions for re-conceptualizing ecotourism, rather than abandoning it all together.

\section{Unpacking the Assumptions Underlying the Classification of Ecotourism as Non-Consumptive Use}

\subsection{NO DIRECT CONSUMPTION OF WILDLIFE OCCURS IN ECOTOURISM}

Using the term 'non-consumptive' to describe ecotourism assumes a separation of ecotourism and the direct consumption of wildlife; however, most definitions of ecotourism do not directly preclude consumptive use. For example, the definition adopted by the IUCN refers to 'enjoying' wild plants and animals (Ceballos-Lascurain 1996), and one interpretation of enjoying could include eating traditional dishes made from local ingredients. Wild game is an important source of protein in many parts of the world, and hunting, fishing, and trapping represent essential activities in many cultures (Freese 1998). Opportunities for incorporating such activities into tourism abound, and combining ecotourism and consumptive use could lead to increased socio-economic returns in some destinations (Freese 1998). Tourists undertaking Inuit-hosted eco-tours, for example, might be invited to attend a community feast that includes locally killed meats (Hinch 1998). Tourists might also participate directly in hunting and/or fishing; USA Today's (2004) '10 Great Places to Tread Lightly On Earth' list of ecotourism destinations, for instance, includes fishing as part of the promoted activities for two destinations (Sell 2004). In Botswana, Kenya, Zimbabwe, and Pakistan, eco-tours that include game hunting provide an important source of revenue to parks and protected areas (Akama 1996; Freese 1998; Mowforth and Munt 1998; Novelli et al. 2006), thus linking consumptive use directly to conservation. Therefore, not only are there examples where ecotourism and consumptive use are combined, there may be further instances where they are compatible. 
Defining ecotourism as non-consumptive perpetuates a Western-influenced, pro-preservation and anti-extraction conception of ecotourism, and masks the heterogeneous nature of peoples, places, and activities that compose ecotourism (Akama 1996; Nygren 2003). The worldviews of many indigenous peoples, for instance, are at-odds with the preservation-focused Western morals that ecotourism is infused with (Hinch 1998). Some indigenous peoples view extractive practices and rituals as an important part of their culture and their interactions with the environment. Defining ecotourism as incompatible with consumption renders these practices incompatible with ecotourism. It also homogenizes the consumptive use of wildlife, denying the diversity of practices and views associated with it, and suggests that "non-consumptive activities refect and convey morally superior values and lead to more intense and desirable experiences' (Tremblay 2001, 83). This in turn limits the potential to use ecotourism as a means of conserving local culture. Hinch $(1998,121)$ suggests that extractive practices that might 'offend the sensibilities of many ecotourists' are often separated from tourists in a spatial or temporal manner, thus denying tourists authentic experiences (MacCannell 1973), because of the values and expectations of ecotourism as non-consumptive (West and Carrier 2004; Carrier and Macleod 2005). Thus, in spite of an emphasis on nature and culture in many ecotourism definitions [as in CeballosLascurain (1996), but see also Wall 1996; Weaver 2005], nature 'trumps' culture when cultural practices do not conform to Western expectations of what ecotourism should be (Carrier and Macleod 2005; Ryan et al. 2000; Weaver 2005). This in turn may prevent ecotourism from achieving its goals of cultural conservation and limit the development of local heritage preservation via tourism. In such instances, outcomes are difficult to predict, but can include increasing tensions between ecotourism/ists and local host communities.

There are examples of local communities attempting to reclaim or take (greater) control of ecotourism development, infusing it with their own values (Johnston 2003; Stronza 2000, 2001; Wall and Long 1996; Wesche 1996). For example, Stronza (2000) details the efforts of the Native Community of Infierno, Peru, to remain a serious partner in their shared ecotourism endeavor with Rainforest Expeditions. Huichols' community assemblies in Mexico are also involved in the planning and running of a Huichol community-based ecotourism program called the Blue Dear Visitors Program, in which tourists, called 'visitors', are placed in Huichol households (Nauman 2002). Australian examples of aboriginal community members' efforts to enter into ecotourism include communitysponsored Aboriginal tour networks and related Web sites (e.g. www.aboriginaltouroperators.com), as promoted by Aboriginal Groups such as Kalkadoon, an Aboriginal women's group (Kalkadoon 2007). While these 
examples do not rely on the extractive use of wildlife per se (although fishing is part of the Australian example), such use is much easier to conceive of within community-controlled ventures; Tremblay (2001) specifically considers the potential compatibility of indigenous lifestyles and cultures with extractive use through recreational hunting and fishing.

\subsection{DIRECT CONSUMPTION OF WILDLIFE IS THE ONLY ISSUE OF CONCERN}

Focusing definitions of ecotourism on the direct interaction of tourism/ ists and wildlife assumes that this interaction is the primary concern in terms of consumption. However, there are other ways in which ecotourism can be consumptive, and three issues are considered below.

First, by focusing on the 'direct removal of the species' in defining consumptive use, the figurative consumption (including visual consumption) associated with ecotourism and impacts thereof are overlooked. Ecotourism, as an act of visual consumption, is similar to mass tourism in that the ecotourist aesthetic, which often demands the appearance of 'pristine nature', is catered to, often as a primary management concern. This frequently involves shielding/separating ecotourists from their own impacts, as well as others. Their exposure to local impacts is also typically limited by the lengths of their stays, which are often relatively short, and the rise of organized eco-tours (Mowforth and Munt 1998; Shepherd 2002; Weaver 2001) that direct ecotourist gazes onto very specific sites, places, and landscapes, and away from other less desirable sights (Ryan et al. 2000; Urry 1995).

Social scientists have contributed greatly to our understanding of 'the Tourist Gaze' (Urry 1995, 2002) and the 'ecotourist gaze' (Hughes and Morrison-Saunders 2003; Hvenegaard and Dearden 1998; Ryan et al. 2000), and how this influences everything from destination images projected (Nelson 2005), to tour content and attraction design (Carrier and Macleod 2005; Luck 2003), to community members' identities (Mowforth and Munt 1998), to local environmental management needs and concerns (Carrier and Macleod 2005; Smith and Duffy 2003). For example, the primacy of visual consumption of environmental features and landscapes in ecotourism can generate undesirable behaviors on the part of guides and/or attraction staff, who may undertake activities such as feeding wild animals so that nature 'performs' for watching ecotourists (Edensor 2001; Evans 1999; Farrell and Marion 2001; Grossberg et al. 2003). Other activities related to visual consumption, like photography, can also have negative impacts on species, especially if they remain neglected (Campbell 1994; Edensor 2001; Grossberg et al. 2003; Ryan et al. 2000). Furthermore, tourists' demands for an ecotourism aesthetic can directly conflict with conservation goals. In Montego Bay, Jamaica, for example, tourists viewed local people fishing (legally) within a marine park as detracting from the park landscape. Park staff felt increasing 
pressure to remove the fishers from the park in order to satisfy the aesthetic expectations of ecotourists, and had little time to devote to environmental issues that they considered to be problematic, such as decreased water quality. Because the latter did not interfere with tourists' visual consumption of the marine landscape, it was difficult for park managers, who were under pressure to ensure tourist satisfaction, to prioritize (West and Carrier 2004). Thus, managing primarily for the ecotourism aesthetic and for figurative consumption of landscapes can result in material consequences for the environment and animal species within it, even if so-called 'consumptive use' (i.e. direct removal of species) is not occurring.

A second consequence of focusing on the 'direct removal of the species' in distinguishing between consumptive and non-consumptive use is that it masks the ways in which ecotourism can consume resources and result in broader negative environmental impacts, beyond those that occur on-site in ecotourist destinations. For example, much ecotourism consists of First World ecotourists or Third World elites traveling to remote destinations abroad. While negative environmental impacts associated with high energy consumption through jet travel are recognized (Gössling 2000), these are typically left out of ecotourism impact assessments because such impacts occur extra-locally, before/after the ecotourist is at their destination. Therefore, the larger ecological footprint of ecotourism as a consumptive activity, from doorstep to destination and back, is not considered (Gössling et al. 2002; Hall 1994; Rees and Wackernagel 1994).

On-site, many eco-destinations include problematic contradictions between tourists' interests in 'nature' and their resource demands. For example, ecotourists might consume high amounts of energy and/or water in hotels, and may demand imported goods that require extensive transport and/or packaging (Gössling and Oliver 2003). Despite theoretical claims regarding ecotourists being more environmentally aware, there is little empirical evidence to support such claims. Ecotourists have been known to consume products such as unsustainable local (or imported) seafood, and problematic 'natural' souvenirs such as shark jaws, corals, and ornamental shells (Gössling and Oliver 2003). These observations have led some scholars to question the existence of the 'ecotourist' as a distinct tourist type (e.g. Duffy 2002; Mowforth and Munt 1998; Weaver 1999; Wheeler 1994).

Lastly, the consumption of goods and services associated with ecotourism often produces a suite of challenging environmental impacts such as waste and sewage generation (Brown et al. 1997; Carrier and Macleod 2005; Garrett 2005; Gössling and Oliver 2003; Lee and Snepenger 1992; Smith and Duffy 2003; Stern et al. 2003; Thrupp 1990; Young 1999). Such impacts are often complicated by the fact that many preferred ecotourist destinations are in places that are located far from impact-related services and infrastructure, and are therefore likely to have limited waste disposal or treatment options available to them (Hillery et al. 2001). 
In Tortuguero, Costa Rica, a well-known ecotourism destination, efforts to manage a growing solid waste problem have been made since the 1990s (Lee and Snepenger 1992; Place 1991; Troëng and Drews 2004). Tortuguero's ability to deal with this problem is arguably constrained by its very success as an ecotourism destination; upward of 80,000 tourists visit Tortuguero each year (De Haro et al. 2005; Harrison et al. 2004), and access to the village and park is by boat or plane, which contributes to the tourist's sense of geographic isolation and 'wilderness'. This same isolation makes solid waste management challenging, as the logistical difficulty and expense of boating or flying garbage and recyclables out of Tortuguero are considerable. That most of the region is protected in a national park also constrains on-site management of garbage. Tortuguero's solid waste management problem reflects an ongoing debate in the wider tourism literature about whether or not the environmental impacts of ecotourism development are actually worse (or at least more difficult to manage) than those associated with mass tourism (Ryan et al. 2000; Weaver 2001). For example, some critics argue that ecotourism might be dispersing the impacts of tourism into more fragile environments where communities lack the resources to manage them (similar to issues faced by small island destinations (Coccossis 2002)). In contrast, mass tourism development has the potential for the concentration of impacts and related infrastructure, and thus for improving environmental efficiency (Brown et al. 1997; Pleumarom 1999; Wall and Long 1996; Weaver 1998). While this debate is rarely reflected in the conservation literature, it illustrates the ways in which some of the original assumptions about ecotourism are being questioned.

Third, by focusing on whether or not wildlife or other environmental features are consumed, the role of ecotourism in consuming cultures is ignored. While definitions of ecotourism often reference both environment and culture, ecotourism's overall focus on 'pristine nature' (Akama 1996) means local people often end up being underemphasized or ignored. When they are included as part of the ecotourism attraction, they are often or portrayed as stereotypes (e.g. indigenous peoples as ecocentric noble savages; Bryant and Goodman 2004; Hinch 1998; Mowforth and Munt 1998; Urry 1995), and rich and complicated cultures are reduced to snapshots or themes for tourists to consume (e.g. Tibet as a theme in Ateljevic and Doorne 2005). Considered to be part of the landscape by the ecotourist gaze, if they are seen at all, local peoples must conform to the images imposed on them through the ecotourism aesthetic, and remain in a stage of suspended animation (e.g. not wearing overly modern dress) and/or live as exaggerated versions of their culture that do not represent its current reality (Hinch 1998; Carrier and Macleod 2005), a process that Mowforth and Munt (1998) refer to as 'zooification' of culture. This creation of a 'staged authenticity' or an artificial version of the destination in order to suit tourist needs, expectations, and desires 
(MacCannell 1973) can lead to the suppression (or segregation) of their actual modern culture (Hinch 1998) and/or to hostility and resistance to ecotourism and the constraints it places on local culture and identities (Campbell et al. forthcoming; Doxey 1975; Meletis and Campbell forthcoming; Smith and Duffy 2003). Furthermore, locating consumptive use (hunting, fishing) outside of acceptable on-site practices in an ecotourismbased community, by the outright forbidding of such practices (e.g. through park-related legislation) or by pushing them into the destination's 'backstage' (MacCannell 1999) could also drive 'an elusive wedge between hosts and guests' (Tremblay 2001, 84).

On-site consumption of goods and services can also have undesirable impacts on local culture and society. Selling souvenirs, for example, might be linked to the commodification of local culture, the re-enforcement of local stereotypes, and/or adversely affecting local culture or identities in other ways (Garrett 2005; Goss 2004; Mowforth and Munt 1998; Nelson 2005). Local people are not simply passive victims of ecotourism development and the commodification of their culture that it may bring, however, and the consumptive relationship between host and guest is dialectical, with the degree of local involvement in 'embodiments of production and consumption' and the negotiation of local images varying from place to place (Ateljevic and Doorne 2005). Local entrepreneurs learn from ecotourists, for example in determining how to sell their products/tours as being 'more authentic' than others, thus 'blurring' the boundaries between consumption and production (Ateljevic and Doorne 2005) and revealing the importance of figurative consumption and the aesthetics of ecotourism as forces that shape the industry. Nonetheless, the consumption of culture, identity, and peoples is occurring on many levels through ecotourism, and this can have negative impacts on local peoples (discussed further below).

2.4 NON-CONSUMPTIVE USE VIA ECOTOURISM IS SUPERIOR TO CONSUMPTIVE USE OF WILDLIFE, FOR ENVIRONMENTS, ECONOMIES, AND PEOPLES

Contrasts made between consumptive use of wildlife and non-consumptive use via ecotourism are typically employed to paint non-consumptive use as inherently more beneficial for both environments and people (Campbell 2002a, b, c). For example, a recent World Wildlife Fund publication, Money Talks, promotes sea turtle based ecotourism over consumptive use of turtles and makes the following claim:

Non-consumptive use generates more revenue, has greater economic multiplying effects, greater potential for economic growth, creates more support for management, and generates proportionally more jobs, social development and employment opportunities for women than consumptive use. (Troëng and Drews 2004, 9) 
Not only is non-consumptive use depicted as more valuable economically, but as incompatible with consumptive use, in both the World Wildlife Fund and other studies:

Non-consumptive economic values [of sea turtles] show the opportunity costs of consumptive uses (e.g. meat, eggs) and incidental destruction (e.g. from boat strikes, entanglement in prawn trawls and crab pots) of sea turtles. (Wilson and Tisdell 2001, 279)

Such claims may apply in some places, but there are counter examples where ecotourism and direct consumptive use of wildlife co-exist. For example, in the Ostional Wildlife Refuge, Costa Rica, a legalized harvest of sea turtle eggs co-exists with turtle-based ecotourism (Campbell 1998, 1999). In this case, consumptive use has emerged as the preferred economic option for most community members. The legalized egg harvest is community-controlled, and sale of sea turtle eggs has been on-going for over 20 years. It provides substantial economic benefits that are widely distributed in the community (Campbell 1998; Campbell et al. 2007). In contrast, existing tourism development in Ostional, while lucrative for those involved, benefits few local families and is increasingly dominated by foreign investors (Campbell 1999). While local people see the benefits of tourism and most are in favor of its expansion, there is little to no desire to replace the egg harvest with tourism, and most local people do not see these activities as incompatible (Campbell et al. 2007). Furthermore, whereas current management of the turtle egg harvest lies with community members and the benefits are distributed in an agreed upon way, there is no guarantee that the benefits from the expansion of local ecotourism development would be distributed similarly, and there is concern among local people about the ability to capture and retain benefits locally (Campbell et al. forthcoming). In the case of Ostional, the consumptive use of wildlife is also believed to be environmentally sustainable, with no evidence of decreases in the numbers of nesting turtles over time (Ballestero et al. 2000), despite the direct removal of the eggs of a species classified as endangered by the IUCN.

While labeling ecotourism non-consumptive implies that ecotourism is 'naturally' less damaging to the environment than consumptive uses of wildlife, there is nothing inherent in ecotourism that guarantees minimal or negligible environmental outcomes, just as consumptive use will not always lead to the depletion of the resources consumed. The impacts (positive and negative) of ecotourism as a form of development depend on a host of factors such as the quality of planning and management involved (Nelson 1994; Wall 1996; Weaver 1998), the cultural appropriateness of ecotourism as a form of development (Boyd and Butler 1996; Charnley 2005; Scheyvens 1999, 2002), the level of impact management (Boyd and Butler 1996; Ross and Wall 1999a), the volume and type of ecotourism visitation to an area (Weaver 1999; Young 1999), and the resiliency of the 
local environment vis-à-vis ecotourism's impacts (Bhattarai et al. 2005; Weaver 1998). Just like any other form of development, ecotourism can be well planned for and managed or poorly planned for and managed (Shepherd 2002). Case study literature details repeated examples of ecotourism development that has included negative impacts on wildlife and the environment, and of ecotourism acting 'as a double-edged sword, with its "success" causing the eventual destruction of the resources being protected' (Campbell 2002b, 41).

Ecotourism can also change consumption patterns and preferences in local communities, with impacts on economy, society, and environment. When ecotourists arrive in a destination, they bring their level of consumption with them in their dress, in their on-site demands, and in representations of their lifestyles found in their daily interactions with local people. This can have profound impacts on local communities, particularly those that are more remote, if local people then aspire to achieve the same material status as tourists, a phenomenon long associated with tourism and known as the demonstration affect (Bhattarai et al. 2005; Carrier and Macleod 2005; Weaver 1998). The point here is not to question whether changing local demand for income and goods is a 'good' or 'bad' thing; concern for the demonstration effect can be interpreted as paternalistic and neo-colonial (i.e. as an effort to freeze local communities as a phase of (lesser) development). Rather, we highlight the demonstration effect to point to the complex network of consumption-related relationships between ecotourism, ecotourists, and host communities that may be overlooked when ecotourism is described as 'non-consumptive', a label that does not capture ecotourism's role in the importation of First World lifestyles and consumption levels to ecotourism destinations.

\section{Situating Ecotourism in Wider Debates about Moralizing Consumption}

In the above sections, we interrogated some of the assumptions associated with popular definitions of ecotourism and its impacts on environments and communities, to illustrate the ways in which the classification of ecotourism as non-consumptive is misleading and can mask the negative consequences of ecotourism for both environments and people. These consequences are well catalogued in the tourism literature (e.g. Cater 2006; Duffy 2002; Honey 1999; Mowforth and Munt 1998; Weaver 1999; Wheeler 1994). In this section, we take a step back from ecotourism in practice and its impacts, to situate ecotourism in wider contemporary debates about the nature of consumption, and specifically about current trends in 'moralizing' consumption and tourism (Bryant and Jarosz 2004; Butcher 2003).

The world has been described as increasingly consumption-driven, a trend that affords consumers power and that gives acts of consumption political meaning (Miller 1995). Consumption is identified as a new site 
for activism and a new locus for civil society (Bryant and Goodman 2004; Butcher 2003), and this has inspired interest in alternative consumption, with consumers expressing their moral preferences through their choice to purchase, for example, fair trade coffee or ecotourism holidays. Ecotourism is portrayed as a way to 'save' nature or particular components of it, in several ways (Campbell et al. forthcoming). First, ecotourism provides an alternative source of income to peoples who, otherwise, would at least partially focus their efforts on the consumptive use of wildlife and/ or other resource extraction (Bryant and Goodman 2004; Campbell 2002a; Clay 2004; Gray 2002; Mowforth and Munt 1998; Smith and Duffy 2003; Tisdell and Wilson 2002). Second, in choosing an ecotourism holiday, ecotourists believe they are reducing impacts on the environment, as ecotourism is also marketed as a more environmentally friendly form of travel (Duffy 2002; Honey 1999; Mowforth and Munt 1998). A narrative of 'ecotourism as helping' is pervasive, and can be found in tourist accounts of their travel experiences, as the example below illustrates:

Afterward, as we stroll back to the village of Tortuguero, I recall my mixed feelings about the human impact on this environment. Now I'm going home joyous that my presence here helped an entire nest of baby turtles survive the first challenge of their lives. (Clay, 2004)

Thus, through consumer choice, acts of consumption are transformed into acts of caring (Miller 1998; Popke 2006), and alternative consumption becomes a moral act (Bryant and Goodman 2004; Bryant and Jarosz 2004; Butcher 2003).

Ecotourism is a particularly interesting form of alternative consumption, for two main reasons. First, Bryant and Goodman (2004) identify two commodity cultures that exist within alternative consumption: (i) conservationseeking (seeking to preserve the environment), and (ii) solidarity-seeking (seeking to support peoples and cultures). While Bryant and Goodman (2004) examine products that fit into one category or the other, ecotourism, at least in theory, combines both, due to its combined goals of wildlife preservation and local economic development. In practice, however, conservation-seeking culture often wins out over the solidarity-seeking, and the need to 'trade-off' between these reveals some of the contradictions inherent in alternative consumption (Campbell et al. forthcoming). Second, unlike many alternative consumption products that face the problem of consumers 'caring-at-a-distance' (Popke 2006), with the object of their concern far removed from them (e.g. regarding organic or fair trade coffees: coffee pickers live far away from First World coffee drinkers), ecotourism brings the caregiver/consumer to the object of the of care/consumption through travel to the site (Barnett et al. 2005). In theory, this should allow for ecotourists as consumers to surmount the challenge of caring-at-adistance. In practice, however, the ecotourist remains distanced from the end results of their act of consumption or 'caring' because, for the most 
part, such impacts (e.g. environmental impacts) remain 'backstage' or are otherwise unobvious to the ecotourist (Edensor 2001; MacCannell 1999).

While some scholars view the trend toward alternative consumption as positive, others are more critical. For example, alternative forms of consumption such as ecotourism may only reaffirm the primacy of both consumption and capitalism, and can be seen as products of neo-liberal economic policies (Campbell 2002b; Campbell et al. forthcoming). Ryan et al. (2000), for example, see ecotourism as a form of consumption first and foremost, and view attempts to portray it as a morally superior undertaking as suspect. All travel for pleasure is form of conspicuous consumption in that it is a function of privilege (e.g. the ability to get time off, to accrue disposable income, to travel to a destination), and, while ecotourism comes in a variety of forms, many ecotourism opportunities are elite, involving travel to remote and expensive destinations (Cater 2006; Hall 1994; Mowforth and Munt 1998; Thrupp 1990). Some experts argue that exclusive ecotourism is desirable precisely because it maximizes profits while minimizing the number of people participating (Akama 1996; Gössling and Oliver 2003; Mowforth and Munt 1998). However, highly affluent clients sometimes present correspondingly high demands for luxury services, and these demands may place significant burdens, environmental and otherwise, on host communities (Bhattarai et al. 2005). There is also a certain irony involved in labeling such an elite form of consumption as non-consumptive.

The moralized discourse of ecotourists as 'caring' also emphasizes what ecotourists put into their travel choices, rather than what they get out of them, such as the cultural capital associated with traveling to the 'right' place to do the 'right' thing, under 'challenging' conditions that ecotourists must endure in order to be able to tell their post-trip tales (Ateljevic and Doorne 2005; Mowforth and Munt 1998; Ryan et al. 2000). Highly exclusive ecotourism opportunities further reinforce a sense of privilege through their limited accessibility; they represent extreme demands regarding location, financing, and social capital that only a 'few' can fulfill. Thus, ecotourism affords a certain cache to the ecotourist and builds their cultural capital, just like drinking organic and/or fair trade coffee does; it serves to mark status and segregate within society, while appealing to those within the same social class (e.g. other ecotourists) (Roseberry 1996). In this light, ecotourism is a product, purchased to fulfill a variety of complex consumer needs.

\section{Re-Conceptualizing Ecotourism}

We have attempted to illustrate the ways in which labeling ecotourism as non-consumptive is misleading. Labeling is not just a matter of semantics, however, and ecotourism's non-consumptive label limits its potential for simultaneously preserving both environments and cultures, down-plays its 
material impacts on both environments and people, and masks its role in larger systems of production and consumption. In this final section, we discuss why the non-consumptive label persists and how we might re-conceptualize ecotourism.

Ecotourism is often closely associated with parks and protected areas, and while the popularity of ecotourism means that it now takes place in a number of different environments, both protected and non-protected, the link between ecotourism and parks and protected areas helps to explain the emphasis put on ecotourism as non-consumptive. Campbell (2002a,c) for example, has argued that promoting ecotourism allows conservationists interested in species preservation to speak the language of a conservation counter-narrative. This arose in opposition to a traditional narrative of exclusionary parks and protected areas, that emphasizes community-based conservation and sustainable use of natural resources, and is related to the more general rise of interest in sustainable development. By promoting non-consumptive use and including goals of cultural conservation and local socio-economic development, ecotourism allows conservationists to adopt this counter-narrative. However, because ecotourism often occurs to parks and protected areas (and can be used to rationalize the creation of more parks), conservationists can speak the language of a counter-narrative while retaining parks and protected areas (the very thing the counter-narrative originally opposed) (Campbell 2002a). By labeling ecotourism non-consumptive, ecotourism 'fits' with the traditionally non-extractive policies of parks, while other consumptive uses do not. More recently, Campbell et al. (forthcoming) have argued that, rather than being a mere outcome of the conservation counter-narrative, ecotourism itself is a narrative; one that persists because it meets the needs of a variety of interest groups (conservationists, tourists, tourism operators, governments), regardless of their views on the best way to pursue conservation and development.

While there are case studies of ecotourism where its goals as currently conceived are realized in practice (e.g. Colvin 1996; Stronza 2000; Wesche 1996; Wunder 2003), more common are those showing ecotourism's disappointments (e.g. Charnley 2005; Duffy 2002; Honey 1999; Kiss 2004; Lindberg et al. 1996). We suggest these disappointments arise at least in part due to the non-consumptive conceptualization of ecotourism in the conservation literature, and the related focus on the direct interaction of tourists and wildlife (or other environmental features of interest). When focusing on such interactions, other impacts are hidden and, therefore, unacknowledged, unanticipated, and unaddressed. As a result, we argue that 'the project of ecotourism' needs to be reconceptualized. This re-conceptualization should recognize ecotourism's consumptive nature in all of the ways outlined in the first part of this article, while simultaneously seeing it as much more than just a product for sale or purchase. 
First, consumptive use should be considered as a possible component of ecotourism, when such use is biologically feasible, socio-economically beneficial, and culturally appropriate and desirable. When consumptive use is possible and included in an ecotourism package, ecotourism might go further in achieving its dual goals of environmental and cultural conservation, with benefits for both environments and people. Furthermore, ecotourism that includes consumptive use might make it more amenable to a wider variety of cultural views from around the world, less Western biased, and more compatible with existing and diverse human-environment relations in potential destinations. Such a shift seems to be more in-line with the wants and desires of many communities and/or indigenous groups interested in self-organized participation in ecotourism (Hinch 1998; Johnston 2003; Wesche 1996). This would also help change our conceptions of ecotourism as simply a service or product being bought and sold, to ecotourism as a process that is negotiated between 'hosts and guests' and between different cultures, worldviews, and value systems.

Second, ecotourism's wider consumptive impacts on the environment, both figurative and literal, should be explicitly recognized as critical to ecotourism planning and management. For example, acknowledging the visual consumption associated with ecotourism forces us to see ecotourist landscapes not as 'natural', but as produced to satisfy an ecotourist aesthetic. Satisfying this has traditionally involved shielding/separating ecotourists from their impacts; ecotourists are often presented with sanitized or 'greenwashed' versions of destinations (Carrier and Macleod 2005; Scheyvens 2002), rather than exposed to local environmental and conservation realities. A re-conceptualized ecotourism could include attention to issues like site management as part of the ecotourism product; ecotourists could be encouraged to look at not only nature, but how it, and its consumption through ecotourism, is managed. This new approach could provide muchneeded opportunities for directed fundraising and/or tourist volunteer work (e.g. for a local recycling program) targeted to specific tourismassociated environmental impacts (e.g. waste management shortcomings), and help to alleviate the environmental pressures felt in some ecotourism destinations. The rise of interest in so-called volunteer ecotourism suggests that this type of engagement is possible. While volunteer ecotourism has itself been critiqued (Campbell and Gray forthcoming), Wearing (2001) forwards it as the ecotourism 'ideal'. At a more fundamental level, recognizing ecotourism is a highly visual and aesthetically oriented form of tourism allows us to more fully contemplate authenticity, or lack thereof, the role of artifice in ecotourism management and marketing, and how management and marketing practices perpetuate or challenge the notion that ecotourism is 'non-consumptive'.

Third, a re-conceptualized vision of ecotourism should give greater emphasis to the consumptive impacts, figurative and literal, of ecotourism on local communities, their natural resources, economies, and cultures. 
While cultural conservation and economic development are included as goals in ecotourism definitions, the assumed superiority of ecotourism to alternative forms of resource use means that impacts of ecotourism on communities are largely assumed to be positive. As long as 'nature trumps culture' for ecotourists, such assumptions are problematic. A move to pay more genuine attention to local people, however, might require concessions such as allowing the consumptive use of wildlife in some ecotourism destinations, and thus the first point of re-conceptualization remains critical.

We believe that re-conceptualizing ecotourism will open up possibilities for improving it, and that due to ecotourism's popularity, looking for possibilities remains important. First, acknowledging the importance of consumption in ecotourism helps to break down the often over-stated distinctions made between ecotourism and mass tourism, and highlights the ways in which these are similar. This provides opportunities for knowledge transfer; conventional tourism, its development, and responses to it have long been studied and there are lessons learned, best practices, and strategies that could be used (both preventatively and responsively) to lessen undesirable consequences of ecotourism development. Acknowledging the role of consumption in both ecotourism and mass tourism creates conceptual space in which such information exchanges can occur, and may lessen the need to 're-invent the wheel' when thinking about and managing ecotourism.

Second, situating ecotourism in the larger trend of moralizing consumption allows us to evaluate it not simply as a form of development or as a leisure activity, but as part of a larger socio-economic phenomenon that involves consumers changing purchasing practices and producers carving out new market niches. As such, ecotourism is similar to other 'alternative' products developed to meet new consumer demands, such as organic and/or fair trade foodstuffs, sweatshop-free textiles, and child labor-free consumer goods. Considering ecotourism in the context of a wider consumer culture opens up new opportunities for making comparisons between such products, the socio-economic processes and industries that produce them, and the people who buy and sell them; looking at ecotourism as consumption also forces us to consider its production. Again, lessons learned with other alternative products may be applied to ecotourism.

Finally, while re-conceptualizing ecotourism should increase the possibilities for ecotourism to contribute to both conservation and development, we also believe that it will allow for more informed decisionmaking about whether or not to undertake ecotourism at all. If we continue to focus only on the 'direct removal of the species' then ecotourism will continue to be, by default, the preferred conservation option; if more animals/resources remain intact, we must be 'better off'. If, however, we broaden our analysis to include wider environmental, economic, cultural and social impacts of ecotourism from the beginning, then all conservation 
and development options may be more realistically assessed for their real costs and benefits.

This article contributes to a growing critique of ecotourism that does not call for an abandonment of ecotourism, but rather for a re-conceptualization of the ways in which we plan for, discuss, and evaluate ecotourism. This re-conceptualization is required in order that ecotourism can achieve its goals in more than a few select cases. Given the association of ecotourism with dominant conservation narratives, and the persistence of narratives in spite of challenges to their validity (Adams and Hulme 2001; Campbell 2002a,b; Roe 1991), the re-conceptualization called for here will not be easily achieved. However, if we are to move beyond restricted visions of ecotourism that conform to (and reconfirm) Western expectations of nature and culture, that carry hidden environmental, social and cultural costs, and that contribute to an 'alternative' consumer culture that does little to challenge the status quo, then such re-conceptualization is necessary and long overdue.

\section{Short Biographies}

Zoë A. Meletis is a PhD candidate at the Nicholas School of the Environment and Earth Sciences, Duke University. Although currently housed in an interdisciplinary environmental school, she is a human geographer. Her thesis compares ecotourism in practice with ecotourism in theory, using the case study of Tortuguero, Costa Rica. She is currently writing up her dissertation. It includes forthcoming manuscripts on local perceptions of ecotourism and conservation in Tortuguero; the solid waste crisis in Tortuguero as an environmental justice issue; an interpretation of local resistance to ecotourism development in the village; and a re-visiting of Susan Place's (1991) assessment of ecotourism in Tortuguero. She recently contributed to a co-authored article published in The Geographical Review on conducting fieldwork in international settings through the use of gatekeepers, and to a chapter (forthcoming) on the political ecology of ecotourism to parks and protected areas. She expects to graduate in December (2007).

Lisa M. Campbell is a geographer and the Rachel Carson Assistant Professor of Marine Affairs and Policy at the Nicholas School of Environment and Earth Sciences, Duke University. Her work is broadly situated at the intersection of environment and development in rural areas of Latin American, the Caribbean, Southern Africa and more recently North Carolina, and is informed by political ecology. She has focused on conservation of endangered species, and specifically of sea turtles, and how conservation conflicts with or enhances local community development. She has authored and co-authored a variety of articles on conservation narratives, policy, and practice, and how these are informed by science and other values, for both geography journals and interdisciplinary environmental studies and development studies journals. She has a recently 
published article in The Annals of the Association of American Geographers on the political ecology of sea turtle conservation.

\section{Acknowledgements}

In writing this article, we draw on field research supported by a number of agencies, including the Social Sciences and Humanities Research Council of Canada, the Nicholas School of the Environment and Earth Sciences at Duke University, Duke University Marine Laboratory, the Duke University Center for Latin American and Caribbean Studies, the Andrew W. Mellon Foundation, and the University of Western Ontario. We would like to thank our 'Campbell lab' colleagues at Duke University Marine Laboratory and our fieldwork communities and friends, Gary Brierley and Helen Ashton at Geography COMPASS, and the two anonymous reviewers for their helpful comments.

\section{Note}

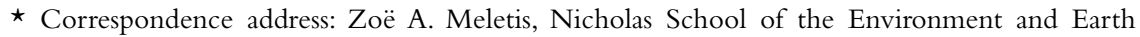
Sciences, Duke University, 135 Duke Marine Lab Road, Beaufort, NC 28516-9721, USA. E-mail: zam@duke.edu.

\section{References}

Adams, W., and Hulme, D. (2001). Conservation and community: changing narratives, policies and practices in African conservation. In: Hulme, D. and Murphree, M. (eds) African wildlife and livelihoods: the promise and performance of community conservation. Oxford, UK: James Curry Ltd., pp. 9-23.

Akama, J. S. (1996). Western environmental values and nature-based tourism in Kenya. Tourism Management 17, pp. 567-574.

Ateljevic, I., and Doorne, S. (2005). Dialectics of authentication: performing 'exotic otherness' in a backpacker enclave of Dali, China. Journal of Tourism and Cultural Change 3, pp. 1-17.

Ballestero, J., Arauz, R. M., and Rojas, R. (2000). Management, conservation, and sustained use of olive ridley sea turtle eggs (Lepidochelys olivacea) in the Ostional Wildlife Refuge, Costa Rica: an 11-year review. In: Abreu-Grobois, F. A., et al. (eds) Proceedings of the eighteenth international sea turtle symposium. Mazatlán, Sinaloa, México: US Department of Commerce, pp. 4-5.

Barnett, C., et al. (2005). Consuming ethics: articulating the subjects and spaces of ethical consumption. Antipode 37, pp. 23-45.

BBC News (2004). Sea turtle decline 'costs millions'. [online]. Retrieved 25 May 2004 from http://news.bbc.co.uk/1/hi/sci/tech/3744661.stm.

Bhattarai, K., Conway, D., and Shrestha, N. (2005). Tourism, terrorism and turmoil in Nepal. Annals of Tourism Research 32, pp. 669-688.

Boyd, S. W., and Butler, R. W. (1996). Managing ecotourism: an opportunity spectrum approach. Tourism Management 17, pp. 557-566.

Brown, K., et al. (1997). Environmental carrying capacity and tourism development in the Maldives and Nepal. Environmental Conservation 24, pp. 316-325.

Bryant, R. L., and Goodman, M. K. (2004). Consuming narratives: the political ecology of 'alternative' consumption. Transactions of the Institute of British Geographers 29, pp. 344-366.

Bryant, R. L., and Jarosz, L. (2004). Ethics in political ecology: a special issue of political geography introduction: thinking about ethics in political ecology (editorial). Political Geography 23, pp. 807-812. 
Butcher, J. (2003). The moralisation of tourism. London: Routledge.

Campbell, C. L. (1994). The effects of flash photography on nesting behavior of green turtles (Chelonia mydas) at Tortuguero, Costa Rica. 14th Annual Symposium on Sea Turtle Biology and Conservation, Hilton Head Island, North Carolina.

Campbell, L. M. (1998). Use them or lose them? Conservation and the consumptive use of marine turtle eggs at Ostional, Costa Rica. Environmental Conservation 24, pp. 305-319.

-. (1999). Ecotourism in rural developing communities. Annals of Tourism Research 26, pp. $534-553$.

12002a). Conservation narratives and the received wisdom of ecotourism: case studies from Costa Rica. International Journal of Sustainable Development, 5, pp. 300-325.

- (2002b). Conservation narratives in Costa Rica: conflict and co-existence. Development and Change 33, pp. 29-56.

- $(2002 \mathrm{c})$. Science and sustainable use: views of marine turtle conservation experts. Ecological Applications 12, pp. 1229-1246.

Campbell, L. M., and Gray, N. J. (forthcoming 2007) A decommodified experience? Exploring aesthetic, economic, and ethical values for volunteer ecotourism in Costa Rica. Journal of Sustainable Tourism 15(5).

Campbell, L. M., Gray, N. J., and Meletis, Z. A. (forthcoming 2007) Political ecology perspectives on ecotourism to parks and protected areas. In: Hanna, K., Clark, D. and Slocombe, S. (eds) Transforming parks and protected areas: management and governance in a changing world. Abingdon, UK: Routledge and Taylor and Francis.

Campbell, L. M., Haalboom, J., and Trow, J. (2007). Sustainability of community based conservation: sea turtle egg harvesting in Ostional (Costa Rica) ten years later. Environmental Conservation 34. Epub ahead of print 25 May 2007. doi: 10.1017/S0376892907003840.

Caribbean Conservation Corporation (2003). Tortuguero national park, Costa Rica-'region of the turtles'. [online]. Retrieved on 11 August 2006 from http://www.cccturtle.org/tortnp.htm

Carrier, J. G., and Macleod, D. V. L. (2005). Bursting the bubble: the socio-cultural context of ecotourism. Journal of the Royal Anthropological Institute 11, pp. 315-334.

Cater, E. (2006). Ecotourism as a Western construct. Journal of Ecotourism 5, pp. 23-39.

Ceballos-Lascuráin, H. (1996). Tourism, ecotourism and protected areas. Gland, Switzerland: IUCN.

Charnley, S. (2005). From nature tourism to ecotourism? The case of the ngorogoro conservation area, Tanzania. Human Organization 64, pp. 75-88.

Clay, K. (2004). A night on the beach with some busy turtles. [online]. Retrieved on 28 August 2006 from http://www.csmonitor.com/2004/1006/p11s02-trgn.html

Coccossis, H. (2002). Island tourism development and carrying capacity. In: Apostopoulos, Y. and Gayle, D. J. (eds) Island tourism and sustainable development. London: Continuum.

Colvin, J. G. (1996). Indigenous ecotourism: the Capirona programme in Napo Province, Ecuador [electronic version]. Unasylva 187.

Conservation International (2004). Conservation international 2004 annual report. Washington, DC: Conservation International. [online]. http://www.conservation.org/ImageCache/CIWEB/ content/about/ci_5f04_5fannual_5freport_2epdf/v1/ci_5f04_5fannual_5freport.pdf.

Cuevas, O., and The Caribbean Conservation Corporation (2002). Tourism development alternative for the turtle fisher community of Limon, Costa Rica. Feasibility Study and Master Plan.

De Haro, A., Troeng, S., and Assistants, A. V. O. R. (2005). Report on the 2005 green turtle program at Tortuguero, Costa Rica. San Pedro, Costa Rica; Gainsville, FL: Caribbean Conservation Corporation.

Doxey, G.V. (1975). A causation theory of visitor-resident irritants: methodology and research inferences. Proceedings of the 6th Travel and Tourism Research Association Conference Proceedings. San Diego, CA: Travel Research Association, pp. 195-198.

Duffy, R. (2002). A trip too far: ecotourism, politics and exploitation. London: Earthscan Publications Ltd.

Edensor, T. (2001). Performing tourism, staging tourism. (Re)producing tourist space and practice. Tourist Studies 1, pp. 59-81.

Evans, S. (1999). The green republic: a conservation history of Costa Rica. Austin, TX: University of Texas Press.

Farrell, T. A., and Marion, J. L. (2001). Identifying and assessing ecotourism visitor impacts at eight protected areas in Costa Rica and Belize. Environmental Conservation 28, pp. 215-225. 
Freese, C. H. (1998). Wild species as commodities: managing markets and ecosystems for sustainability. Washington, DC: Island Press.

Garrett, S. (2005). Poppies and mangoes: women's empowerment, environmental conservation, and ecotourism in Costa Rica. Women and Environments International Magazine Fall 2004/ Winter 2005, pp. 23-25.

Goss, J. (2004). The souvenir: conceptualizing the object(s) of tourist consumption. In: Lew, A. A., Hall, M. C. and Wiliams, A. M. (eds) A companion to tourism. Malden, MA: Blackwell Publishing.

Gössling, S. (2000). Sustainable tourism development in developing countries: some aspects of energy use. Journal of Sustainable Tourism 8, pp. 410-425.

Gössling, S., and Hörstmeier, O. (2003). 'High-value conservation tourism': integrated tourism development in the Seychelles? In: Gössling, S. (ed.) Tourism and development in tropical islands: political ecology perspectives. Cheltenham, UK: Edward Elgar, pp. 203-221.

Gössling, S., et al. (2002). Ecological footprint analysis as a tool to assess tourism sustainability. Ecological Economics 43, pp. 199-211.

Gray, N. (2002). Unpacking the baggage of ecotourism: nature, science and local participation. The Great Lakes Geographer 9, pp. 11-21.

Gray, N. J., and Campbell, L. M. (forthcoming 2007). A decommodified experience? Exploring aesthetic, economic, and ethical values for volunteer ecotourism in Costa Rica. Journal of Sustainable Tourism 15(5).

Grossberg, R., Treves, A., and Naughton-Treves, L. (2003). The incidental ecotourist: measuring visitor impacts on endangered howler monkeys at a Belizean archaeological site. Environmental Conservation 30, pp. 40-51.

Hall, C. M. (1994). Tourism and politics: policy, power, and place. Chichester, UK: John Wiley \& Sons.

Harrison, D. E., Troëng, S., and Assistants, A. V. R. (2004). Report on the 2004 green turtle program at Tortuguero, Costa Rica. San Pedro, Costa Rica: Caribbean Conservation Coroporation.

Hillery, M., et al. (2001). Tourist perception of environmental impact. Annals of Tourism Research 28, pp. 853-867.

Hinch, T. (1998). Ecotourists and indigenous hosts: diverging views on their relationship with nature. Current Issues in Tourism 1, pp. 120-124.

Honey, M. (1999). Ecotourism and sustainable development: who owns paradise? Washington, DC: Island Press.

Hughes, M., and Morrison-Saunders, A. (2003). Visitor attitudes toward a modified natural attraction. Society and Natural Resources 16, pp. 191-203.

Hvenegaard, G. T., and Dearden, P. (1998). Ecotourism versus tourism in a Thai National Park. Annals of Tourism Research 25, pp. 700-720.

Johnston, A. M. (2003). Self-determination: exercising indigenous rights in Tourism. In: Singh, S. T., Dallen J. and Dowling Ross K. (eds) Tourism in destination communities. Wallingford, UK: CABI Publishing, pp. 115-134.

Kalkadoon (2007). Cultural and eco-tourism. [online]. Retrieved on 01 May 2007 from http:// www.kalkadoon.org/index.php/channel-country-tourism/

Kiss, A. (2004). Is community-based ecotourism a good use of biodiversity conservation funds? TRENDS in Ecology and Evolution 19, pp. 233-237.

Lee, D. N. B., and Snepenger, D. J. (1992). An ecotourism assessment of Tortuguero, Costa Rica. Annals of Tourism Research 19, pp. 367-370.

Lindberg, K., Enriquez, J., and Sproule, K. (1996). Ecotourism questioned: case studies from Belize. Annals of Tourism Research 23, pp. 543-562.

Luck, M. (2003). Education on marine mammal tours as agent for conservation - but do tourists want to be educated? Ocean and Coastal Management, 46, pp. 943-956.

Maccannell, D. (1973). Staged authenticity: arrangements of social space in tourist settings. American Journal of Sociology 79, pp. 589-603.

. (1999). The tourist: a new theory of the leisure class. Berkeley, CA: University of California Press.

Meletis, Z. A., and Campbell, L. M. (forthcoming). Appreciation, apprehension, and action? An interpretation of resistance to ecotourism in Tortuguero, Costa Rica. (for submission to GeoForum). 
Miller, D. (1998). A theory of shopping. Ithaca, NY: Cornell University Press.

(ed.) (1995). Acknowledging consumption. London: Routledge.

Mowforth, M., and Munt, I. (1998). Tourism and sustainability: new tourism in the Third World. London: Routledge.

Nauman, T. (2002). Reclaiming a territory and the culture that goes with it. [online]. Retrieved on 01 May 2007 from http://www.changemakers.net/journal/02february/nauman.cfrr

Nelson, J. G. (1994). The spread of ecotourism: some planning implications. Environmental Conservation 21, pp. 248-255.

Nelson, V. (2005). Representation and images of people, place and nature in Grenada's tourism. Geografiska Annaler 87B, pp. 131-143.

Novelli, M., Barnes, J. I., and Humavindu, M. (2006). The other side of the ecotourism coin: consumptive tourism in Southern Africa. Journal of Ecotourism 5, pp. 62-79.

Nygren, A. (2003). Nature as contested terrain: conflicts over wilderness protection and local livelihoods in Rio San Juan, Nicaragua. In: Anderson, D. G. and Berglund, E. (eds) Ethnographies of conservation: environmentalism and the distribution of privilege. New York: Berghan Books.

Place, S. (1991). Nature tourism and rural development in Tortuguero. Annals of Tourism Research 18, pp. 186-201.

Pleumarom, A. (1999). The hidden costs of the 'new' tourisms - a focus on biopiracy. Third World Briefing Paper for CSD7, No. 1. [online]. Retrieved on 27 March 2007 from http:// www.twnside.org.sg/title/hidden.htm/

Popke, J. (2006). Geography and ethics: everyday mediations through care and consumption. Progress in Human Geography 30, pp. 504-512.

Rees, W., and Wackernagel, M. (1994). Ecological footprints and appropriated carrying capacity: measuring the natural capital requirements of the human economy. In: Jansson, M. H. M., Folke, C. and Costanza, R. (eds). Investing in natural capital: the ecological economics approach to sustainability. Washington, DC: Island Press, pp. 362-390.

Roe, E. (1991). Development narratives, or making the best of blueprint development. World Development 19, pp. 287-300.

Roseberry, W. (1996). The rise of yuppie coffees and the reimagination of class in the United States. American Anthropologist 98, pp. 762-775.

Ross, S., and Wall, G. (1999). Ecotourism: towards congruence between theory and practice. Tourism Management 20, pp. 123-132.

Ryan, C., Hughes, K., and Chirgwin, S. (2000). The gaze, spectacle and ecotourism. Annals of Tourism Research 27, pp. 148-163.

Scheyvens, R. (1999). Ecotourism and the empowerment of local communities. Tourism Management 20, pp. 245-249.

—. (2002). Tourism for development: empowering communities. Essex, UK: Prentice Hall, Pearson Education Harlow.

Sell, S. (2004). 10 great places to tread lightly on Earth. USA Today 20 August 2004, p. 3D.

Shepherd, N. (2002). How ecotourism can go wrong: the cases of SeaCanoe and Siam Safari, Thailand. Current Issues in Tourism 5, pp. 309-318.

Smith, D. (2005). La Comunidad. Tortuguero, Costa Rica. Una pelicula sobre la gente y la naturaleza de Tortuguero. Costa Rica: USA Associacion CAVU.

Smith, M., and Duffy, R. (2003). The ethics of tourism development. London: Routledge.

Stern, C. J., et al. (2003). How 'eco' is ecotourism? A comparative case study of ecotourism in Costa Rica. Journal of Sustainable Tourism 11, pp. 322-347.

Stronza, A. (2000). Because it is ours: community-based ecotourism in the Peruvian Amazon. Gainsville, FL: University of Florida.

- (2001). Anthropology of tourism: forging new ground for ecotourism and other alternatives. Annual Review of Anthropology 30, pp. 261-283.

The International Ecotourism Society. (no date given). Ecotourism-definitions and principles. [online]. Retrieved on 12 January 2006 from http://www.ecotourism.org

Thrupp, L. A. (1990). Environmental initiatives in Costa Rica: a political ecology perspective. Society and Natural Resources 3, pp. 243-256.

Tisdell, C., and Wilson, C. (2002). Ecotourism for the survival of sea turtles and other wildlife. Biodiversity and Conservation 11, pp. 1521-1538. 
Tremblay, P. (2001). Wildlife tourism consumption: consumptive or non-consumptive. International Journal of Tourism Research 3, pp. 81-86.

Troëng, S. (2004). Five decades of sea turtle conservation, monitoring and research at Tortuguero. Tortuguero, Costa Rica: Tortuga Lodge.

Troëng, S., and Drews, C. (2004). Money talks: economic aspects of marine turtle use and conservation. Gland, Switzerland: WWF-International.

Urry, J. (1995). Consuming places. London: Routledge. . (2002). The tourist gaze. Thousand Oaks, CA: SAGE Publications London.

Wall, G., and Long, V. (1996). Balinese homestays: an indigenous response to tourism opportunities. In: Butler, R. and Hinch, T. (eds) Tourism and indigenous peoples. London: International Thomson Business Press, pp. 27-48.

Wall, G. (1996). Ecotourism: change, impacts, and opportunities. Yale School of Forestry, and Environmental Studies Bulletin Series 99, pp. 108-117.

Wearing, S. (2001). Volunteer tourism: experiences that make a difference. New York: CABI publishing. Weaver, D. B. (1998). Ecotourism in the less developed world. Wallingford, UK: CAB International. . (1999). Magnitude of ecotourism in Costa Rica and Kenya. Annals of Tourism Research 26, pp. $792-816$.

- (2001). Ecotourism as mass tourism: contradiction or reality? Cornell Hotel and Restaurant Administration Quarterly 42, pp. 104-112.

- (2005). Comprehensive and minimalist dimensions of ecotourism. Annals of Tourism Research 32, pp. 439-455.

Wesche, R. (1996). Developed country environmentalism and indigenous community controlled ecotourism in the Ecuadorian Amazon. Geographische Zeitschrift 84, pp. 157-168.

West, P., and Carrier, J. G. (2004). Ecotourism and authenticity: getting away from it all? Current Anthropology 45, pp. 483-498.

Wheeler, B. (1994). Egotourism, sustainable tourism and the environment: a symbiotic, symbolic or shambolic relationship. In: Seaton, A.V. (ed.) Tourism: the state of the art. Chichester, UK: John Wiley \& Sons, pp. 645-654.

Wilson, C., and Tisdell, C. (2001). Sea turtles as a non-consumptive tourism resource especially in Australia. Tourism Management 22, pp. 279-288.

. (2003). Conservation and economic benefits of wildlife-based marine tourism: sea turtles and whales as case studies. Human Dimensions of Wildlife 8, pp. 49-58.

Wunder, S. (2003). Native tourism, natural forests and local incomes in Ilha Grande, Brazil. In: Gössling, S. (ed.) Tourism and development in tropical islands: political ecology perspectives. Cheltenham, UK: Edward Elgar Publishing, pp. 148-177.

Young, E. H. (1999). Balancing conservation with development in small-scale fisheries: is ecotourism an empty promise? Human Ecology 27, pp. 581-620. 